\title{
Abscisic Acid Priming Creates Alkaline Tolerance in Alfalfa Seedlings (Medicago sativa L.)
}

\author{
Tian-Jiao Wei ${ }^{1,2}$, Ming-Ming Wang ${ }^{1,3}$, Yang-Yang Jin ${ }^{1}$, Guo-Hui Zhang ${ }^{1}$, Miao Liu ${ }^{1,3}$, Hao-Yu Yang ${ }^{1,3}$, \\ Chang-Jie Jiang ${ }^{4, *}$ and Zheng-Wei Liang ${ }^{1,3, *}$
}

1 Northeast Institute of Geography and Agroecology, Chinese Academy of Sciences, Changchun 130102, China; weitianjiao@iga.ac.cn (T.-J.W.); wangmingming@iga.ac.cn (M.-M.W.); jinyangyang@iga.ac.cn (Y.-Y.J.); zhangguohui@iga.ac.cn (G.-H.Z.); liumiao@iga.ac.cn (M.L.); yanghaoyu@iga.ac.cn (H.-Y.Y.)

2 University of Chinese Academy of Sciences, Beijing 100049, China

3 Da'an Sodic Land Experiment Station, Da'an 131317, China

4 Institute of Agrobiological Sciences, NARO, Kannondai 2-1-2, Tsukuba 305-8642, Japan

* Correspondence: cjjiang@affrc.go.jp (C.-J.J.); liangzw@iga.ac.cn (Z.-W.L.); Tel.: +81-29-8388385 (C.-J.J.); +86-431-85542347 (Z.-W.L.)

Citation: Wei, T.-J.; Wang, M.-M.; Jin, Y.-Y.; Zhang, G.-H.; Liu, M.; Yang, H.-Y.; Jiang, C.-J.; Liang, Z.-W. Abscisic Acid Priming Creates Alkaline Tolerance in Alfalfa Seedlings (Medicago sativa L.) Agriculture 2021, 11, 608. https:// doi.org/10.3390/agriculture11070608

Academic Editor: Valya Vassileva

Received: 31 May 2021

Accepted: 28 June 2021

Published: 29 June 2021

Publisher's Note: MDPI stays neutral with regard to jurisdictional claims in published maps and institutional affiliations.

Copyright: (c) 2021 by the authors. Licensee MDPI, Basel, Switzerland. This article is an open access article distributed under the terms and conditions of the Creative Commons Attribution (CC BY) license (https:// creativecommons.org/licenses/by/ $4.0 /)$.

\begin{abstract}
Soil alkalization triggers ion toxicity and osmotic and alkaline (high $\mathrm{pH}$ ) stresses in plants, damaging their growth and productivity. Therefore, we investigated whether priming with abscisic acid (ABA) increases the tolerance of alfalfa seedlings to alkaline stress, and then examined the underlying molecular mechanisms. Alfalfa seedlings were pretreated with ABA $(10 \mu \mathrm{M})$ for $16 \mathrm{~h}$ and then subjected to alkaline stress using a $15 \mathrm{mM} \mathrm{Na}_{2} \mathrm{CO}_{3}$ solution ( $\mathrm{pH}$ 10.87). Compared with the control, ABA pretreatment significantly alleviated leaf damage and improved the fresh weight, water content, and survival rate of alfalfa seedlings under alkaline conditions. Abscisic acid pretreatment reduced accumulation of reactive oxygen species (ROS), increased activities of the antioxidant enzymes superoxide dismutase (SOD) and peroxidase (POD), maintained higher ratios of $\mathrm{K}^{+} / \mathrm{Na}^{+}$, $\mathrm{Ca}^{2+} / \mathrm{Na}^{+}$, and $\mathrm{Mg}^{2+} / \mathrm{Na}^{+}$, and increased accumulation of proline. In addition, $\mathrm{ABA}$ upregulated the expression of genes involved in proline biosynthesis (P5CS) and the sequestration of $\mathrm{Na}^{+}$in vacuoles (NHX1 and $A V P$ ) under alkaline conditions. Abscisic acid priming increased tolerance to alkaline stress by maintaining homeostasis of ROS and metal ions and upregulating osmoprotection and the expression of stress tolerance-related genes.
\end{abstract}

Keywords: abscisic acid priming; alkaline stress; reactive oxygen species; ion homeostasis; stress tolerance-related genes; alfalfa (Medicago sativa L.)

\section{Introduction}

Saline-alkaline (SA) stress is one of the major abiotic factors severely limiting plant growth and development, and lowers grain yield [1,2]. Approximately $955 \times 10^{6}$ ha of arable land worldwide face the threat of soil salinization-alkalization [3,4]. High $\mathrm{pH}$, in addition to high $\mathrm{Na}^{+}$content $\left(\mathrm{Na}_{2} \mathrm{CO}_{3}\right.$ or $\left.\mathrm{NaHCO}_{3}\right)$, characterizes SA stress $[5,6]$ which has more complex adverse effects on plants than neutral saline stress [7]. Saline-alkaline stress results in osmotic damage to the cell membrane systems by producing excess levels of reactive oxygen species (ROS) and increasing oxidation [5,8-10]. A higher $\mathrm{pH}$ in the rhizosphere resulting from SA stress causes severe damage to the root cells and disturbs ion homeostasis, resulting in plant nutrient deficiencies [5,10-12]. However, our understanding of the physiological and molecular mechanisms underlying plant responses to SA stress is still limited [1,8-10].

To adapt to the stresses, plants generally employ multiple cross-talk strategies, including the regulation of metabolism and gene expression for physiological and morphological adaptation [13,14]. At present, the mechanisms of salt tolerance have been extensively characterized by investigating the efflux of $\mathrm{Na}^{+}$from roots to soil, sequestration of $\mathrm{Na}^{+}$in 
vacuoles, retrieval of $\mathrm{Na}^{+}$from the xylem, increased tolerance to high $\mathrm{Na}^{+}$concentrations, and accumulation of compatible solutes $[13,15]$. Plants usually increase the concentration of cell fluid and lower the osmotic potential by actively accumulating a variety of organic substances, such as proline and soluble sugars, thus maintaining cell swelling and normal physiological metabolic activities $[13,16]$. Plants usually respond to SA stress by maintaining $\mathrm{K}^{+}$uptake, increasing $\mathrm{Na}^{+}$compartmentalization $[13,17]$, and increasing $\mathrm{Ca}^{2+}$ and $\mathrm{Mg}^{2+}$ levels $[2,10,18]$. These findings indicate that ion homeostasis plays an important role in plant response to SA stress. Plants can also increase their tolerance to alkalinity by increasing the activities of antioxidant enzymes, such as superoxide dismutase (SOD), catalase (CAT), peroxidase (POD), and ascorbate peroxidase (APX), and nonenzymatic antioxidant compounds, including ascorbic acid (ASH) and glutathione (GSH) $[9,10,19,20]$.

Alfalfa (Medicago sativa L.) is considered to be a pioneer pasture plant because of its high yield and its tolerance to saline and SA stress [2,13]. In general, SA stress inhibits seed germination and restricts alfalfa seedling growth $[1,6,12,21]$ and destroys the ion balance [12] and ROS homeostasis [1,6], ultimately affecting the normal growth and metabolism of alfalfa. Consistent with these results, SA stress in the field also inhibits alfalfa shoot dry mass and stem length, and the $\mathrm{Ca}^{2+} / \mathrm{Na}^{+}$ratio was identified as a critical marker in evaluating SA tolerance [2]. Moreover, several abiotic stress-responsive genes in alfalfa have been reported, such as the genes encoding ROS-scavenging enzymes $(\mathrm{CuZnSOD}$, $P O D)$ [15], antiporters / ATPase protein (NHX1, AVP) [15,22,23], and proline biosynthase (P5CS) $[15,24]$. These findings confirm that stress tolerance is associated with ROS, ion homeostasis, osmotic balance, and relative gene expression.

As a small liposoluble phytohormone, abscisic acid (ABA) plays an important role in plant responses to various abiotic stresses, such as salinization [25], drought [26], and chilling injury [27]. Priming (also known as hardening, sensitization, and potentiation) is thought to be a major pathway for the rapid acquisition of defense capabilities by plants in response to stress $[28,29]$. ABA pretreatment (priming) can significantly improve plant tolerance to abiotic stresses. Under salt stress, Brassica napus seeds pretreated with ABA show earlier germination and greater radical initiation than a mock control [30]. Gurmani et al. [31] found that seed-soaking with ABA improves the salt tolerance of rice by inhibiting the absorption of $\mathrm{Na}^{+}$and $\mathrm{Cl}^{-}$. $\mathrm{ABA}$ priming increases the tolerance of rice to alkaline stress [11,32]. Liu et al. [9]. reported that ABA pretreatment significantly increases antioxidant enzyme activity and improves the survival rate of rice seedlings. Exogenous ABA increases salt tolerance of alfalfa [33] and alleviates cold stress injury [34]. However, as a defense against alkaline stress, the use of ABA priming in alfalfa seedlings has not yet received much attention.

In this study, we investigated the priming effect of $A B A$ on alkaline tolerance in alfalfa seedlings, and elucidated the underlying mechanisms. The priming with ABA significantly increased alkaline tolerance in alfalfa seedlings by increasing proline content, maintaining ROS and ion homeostasis, and upregulating the expressions of the stress tolerance-related genes.

\section{Materials and Methods}

\subsection{Plant Material and Growth Conditions}

Alfalfa (Medicago sativa L. 'Longmu No. 803') seeds were sterilized with a $6 \%$ sodium hypochlorite solution for $10 \mathrm{~min}$, rinsed with distilled water three times, and then germinated in plastic pots $(25 \mathrm{~cm}$ diameter $\times 20 \mathrm{~cm}$ depth) filled with vermiculite. The seedlings were cultured in a tray soaked with distilled water for $10 \mathrm{~d}$ and then Hoagland's nutrient solution for another 7 days. Twenty-one uniformly grown seedlings were secured onto seven custom sponges, three plants on each custom sponge, in a $320 \mathrm{~mL}$ plastic cup. Each treatment consisted of three plastic cups. A controlled growth chamber was set to $25^{\circ} \mathrm{C}$ day $/ 20^{\circ} \mathrm{C}$ night with a $12 \mathrm{~h}$ photoperiod at $350 \mu \mathrm{mol}$ photons $\mathrm{m}^{-2} \mathrm{~s}^{-1}$ light intensity. All experiments were performed with three biological replicates. 


\subsection{Alkaline Stress Treatment and Abscisic Acid Application}

Based on a preliminary experiment, we selected $15 \mathrm{mM}$ of $\mathrm{Na}_{2} \mathrm{CO}_{3}(\mathrm{pH}=10.87$, electrical conductivity $(\mathrm{EC})=2.72 \mathrm{mS} \mathrm{cm}^{-1}$ ) to simulate alkaline stress (Figure S1), and $10 \mu \mathrm{M}$ of $\mathrm{ABA}$ and fluridone as the treatment concentration (Figure S2). The EC and $\mathrm{pH}$ of solutions were measured using a DDS-12 conductivity meter (Lida Inc., Shanghai, China) and a PHS-25 pH meter (Baiyuan Inc., Beijing, China), respectively. ABA (Sigma, Inc., St. Louis, MO, USA) or fluridone (Sigma, Inc., St. Louis, MO, USA, an ABA biosynthesis inhibitor, as the negative control) was dissolved in a small amount of absolute ethanol and then diluted with deionized water to the desired concentration.

For the ABA priming experiment, the eighteen-day-old alfalfa seedlings were separately transferred to the plastic cups containing 0 (control) or $10 \mu \mathrm{M}$ ABA or fluridone in a dark environment for $16 \mathrm{~h}$, then transferred to solutions containing 0 (unstressed) or $15 \mathrm{mM} \mathrm{Na}_{2} \mathrm{CO}_{3}$ in the absence of $\mathrm{ABA}$ or fluridone. The seedlings were sampled for analysis after $24 \mathrm{~h}, 36 \mathrm{~h}, 48 \mathrm{~h}$, and $60 \mathrm{~h}$.

\subsection{Measurement of Leaf Withering Rate, Seedling Survival, and Growth under Alkaline Conditions}

The leaf withering rate per seedling with or without ABA pretreatment was recorded after $24,36,48$, and $60 \mathrm{~h}$ of $\mathrm{Na}_{2} \mathrm{CO}_{3}$ stress. The survival of alfalfa seedlings with or without ABA pretreatment was determined after $48 \mathrm{~h}$ and $60 \mathrm{~h}$ of $\mathrm{Na}_{2} \mathrm{CO}_{3}$ stress. Individual seedlings were classified as dead when all the leaves were dry and brown. The total fresh weight of individual plants was measured after $60 \mathrm{~h}$ of $\mathrm{Na}_{2} \mathrm{CO}_{3}$ treatment. The samples were then dried in a forced air-driven oven at $105{ }^{\circ} \mathrm{C}$ for $20 \mathrm{~min}$, followed by $70{ }^{\circ} \mathrm{C}$, until a stable mass was reached, before the determination of the dry weight of individual plants. The water content was calculated by the following formula: (fresh weight - dry weight) / fresh weight $\times 100 \%$.

\subsection{Measurement of Chlorophyll Contents, Malondialdehyde, Reactive Oxygen Species, and Antioxidant Enzyme Activities}

The chlorophyll content was determined according to the method of Zhang et al. [8]. Total chlorophyll content was calculated using the following formula: $(8.02$ OD663 nm + $20.21 \mathrm{OD} 645 \mathrm{~nm}) \times \mathrm{V} / 1000 \mathrm{~W}$. The contents of the $\mathrm{ROS}\left(\mathrm{H}_{2} \mathrm{O}_{2}\right.$ and $\left.\mathrm{O}_{2}{ }^{--}\right)$, SOD, and POD were measured by the method of Zhang et al. [8]. The malondialdehyde (MDA) content was determined by the method of Liu et al. [9]. The MDA content was calculated using the following formula: $6.45 \times(\mathrm{A} 532-\mathrm{A} 600)-0.56 \times \mathrm{A} 450$.

\subsection{Measurement of Proline and Metal Ion Contents}

The proline content was determined according to the modified method by Bates et al. [35]. Specifically, approximately $50 \mathrm{mg}$ of a dry powder sample from shoots was homogenized in $5 \mathrm{~mL}$ of $3 \%(w / v)$ sulfosalicylic acid in $15 \mathrm{~mL}$ plastic tubes, and then the mixture was placed in a boiling water bath for $10 \mathrm{~min}$. The plastic tubes were cooled and then centrifuged at $3000 \times g$ for $20 \mathrm{~min}$. Approximately $2 \mathrm{~mL}$ of the supernatant was mixed with $2 \mathrm{~mL}$ of glacial acetic acid and $2 \mathrm{~mL}$ of acidic ninhydrin reagent and then boiled for $30 \mathrm{~min}$. The plastic tubes were cooled, $4 \mathrm{~mL}$ of toluene was added to each tube, and the absorbance at $520 \mathrm{~nm}$ was determined with a spectrophotometer (T6, Puxi General Instrument Co., Ltd., Beijing, China).

To determine the contents of metal ions, approximately $0.1 \mathrm{~g}$ of dry powder from each sample was digested with a mixture of $\mathrm{HNO}_{3}$ and $\mathrm{HClO}_{4}(v / v=2: 1)$ and then diluted to $100 \mathrm{~mL}$. The total contents of the cations $\mathrm{Na}^{+}, \mathrm{K}^{+}, \mathrm{Ca}^{2+}$, and $\mathrm{Mg}^{2+}$ in the mixture were determined as previously described using an inductively coupled plasma mass spectrometer (ICPS-7500, Shimadzu Corporation, Kyoto, Japan) [2]. The ratios of $\mathrm{K}^{+} / \mathrm{Na}^{+}$, $\mathrm{Ca}^{2+} / \mathrm{Na}^{+}$, and $\mathrm{Mg}^{2+} / \mathrm{Na}^{+}$in alfalfa leaves were also calculated. 


\subsection{RNA Isolation and Reverse Transcription Quantitative PCR}

Fresh alfalfa leaves $(0.2 \mathrm{~g})$ were harvested from each treatment, frozen in liquid nitrogen, and ground using a benchtop ball mill at $50 \mathrm{~Hz}$ for $30 \mathrm{~s}$. Total RNA was extracted using TRIzol reagent (TaKaRaBio, Co., Ltd., Tokyo, Japan), and the first-strand cDNA was biosynthesized using EasyScript ${ }^{\circledR}$ One-Step gDNA Removal and cDNA Synthesis SuperMix (TransGen Technologies, Co., Ltd., Beijing, China) following the manufacturer's instructions. The POD, CuZnSOD, AVP, NHX1, and P5CS accession numbers (GenBank/miRBase) and primers are shown in Table S1 [15,36-38]. These genes are involved in antioxidant enzyme synthesis, ion transport, and proline synthesis. The housekeeping gene Actin 2 (GenBank ID: JQ028730.1) was selected as the internal standard due to its stable expression levels in different tissues under various different conditions [38]. The PCR reaction mixture $(20 \mu \mathrm{L})$ contained $1.6 \mu \mathrm{L}$ of cDNA template, $0.4 \mu \mathrm{L}$ of $10 \mu \mathrm{M}$ specific forward primer, $0.4 \mu \mathrm{L}$ of $10 \mu \mathrm{M}$ specific reverse primer, $10 \mu \mathrm{L}$ of $2 \times$ SYBR PremixEx Taq (TaKaRaBio, Co., Ltd., Tokyo, Japan), and $7.6 \mu \mathrm{L}$ of double-distilled $\mathrm{H}_{2} \mathrm{O}$ and was run in a PCR max machine (Eco TM 48, Illumina, Saffron Walden, UK). The procedure was conducted as follows: 1 cycle at $95^{\circ} \mathrm{C}$ for $30 \mathrm{~s} ; 40$ cycles at $95^{\circ} \mathrm{C}$ for $15 \mathrm{~s}, 58^{\circ} \mathrm{C}$ for $30 \mathrm{~s}$, and $72{ }^{\circ} \mathrm{C}$ for $30 \mathrm{~s}$; and 1 cycle at $95^{\circ} \mathrm{C}$ for $15 \mathrm{~s}, 60^{\circ} \mathrm{C}$ for $1 \mathrm{~min}$, and $95^{\circ} \mathrm{C}$ for $15 \mathrm{~s}$ for melting curve analysis. The level of relative expression was calculated using the $2^{-\triangle \triangle \mathrm{CT}}$ method [39].

\subsection{Statistical Analyses}

The leaf withering rate and survival rate in Figure 1 were analyzed using a Student's $t$-test, and the asterisks denote a significant difference compared with control plants at the level of $p<0.05$ or $* * p<0.01$. The other data were analyzed using one-way ANOVA, followed by Duncan's multiple range tests. $p$-values $<0.05$ were considered as statistically significant. All tests were performed in SPSS v 20.0 for Windows (SPSS, Chicago, IL, USA).

A

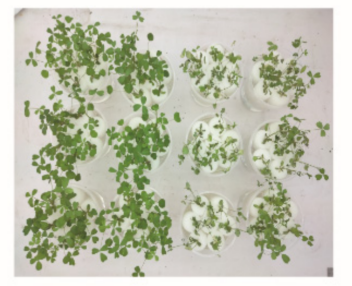

Control $\mathrm{ABA} \mathrm{Na} \mathrm{CO}_{3} \mathrm{ABA}+\mathrm{Na}_{2} \mathrm{CO}_{3}$
B

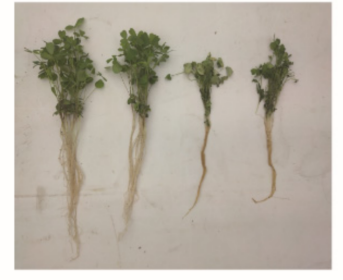

Control $\mathrm{ABA} \mathrm{Na} \mathrm{CO}_{3} \mathrm{ABA}+\mathrm{Na}_{2} \mathrm{CO}_{3}$
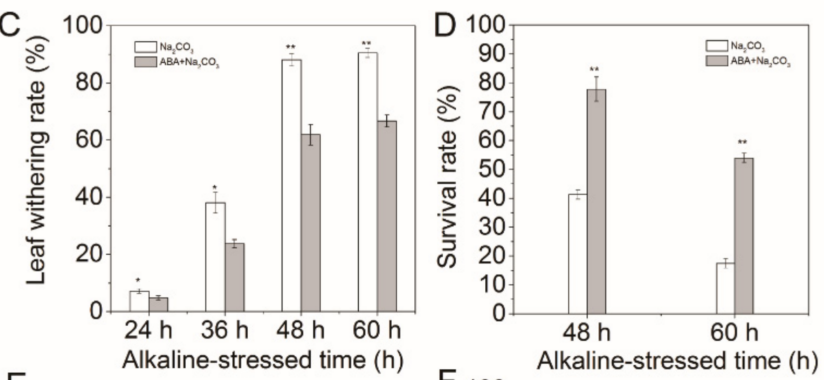

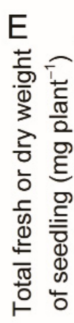

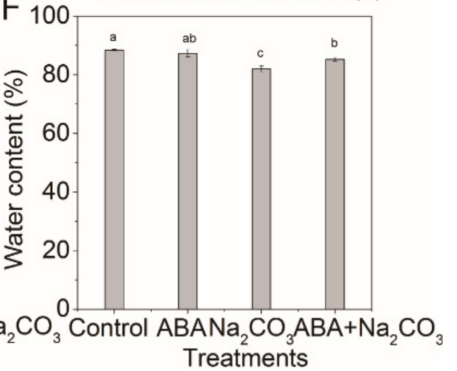

Figure 1. Abscisic acid (ABA) priming protected alfalfa (Medicago sativa L.) seedlings from wilting and death under alkaline conditions. Eighteen-day-old alfalfa seedlings were root-drenched with 
$10 \mu \mathrm{M}$ ABA or without $10 \mu \mathrm{M}$ ABA (Control) for $16 \mathrm{~h}$ and then exposed to alkaline stress (15 mM $\left.\mathrm{Na}_{2} \mathrm{CO}_{3}\right) .(\mathbf{A}, \mathbf{B})$ Photographs of seedling growth were taken after $60 \mathrm{~h}$ of alkaline treatment, (C) leaf withering (\%) was recorded at $24 \mathrm{~h}, 36 \mathrm{~h}, 48 \mathrm{~h}$, and $60 \mathrm{~h}$, (D) survival rate of alfalfa seedlings was determined after $48 \mathrm{~h}$ and $60 \mathrm{~h}$ of alkaline treatment, (E) total fresh or dry weight of seedlings and (F) water content were measured after $60 \mathrm{~h}$ of alkaline treatment. Values are the mean \pm standard error, $\mathrm{n}=3$. Asterisks denote a significant difference compared with control plants $\left({ }^{*} p<0.05,{ }^{* *} p<0.01\right)$ based on Student's $t$-test. Different letters above the columns indicate significant differences $(p<0.05)$ at each time point based on Duncan's test.

\section{Results}

\subsection{Priming with Abscisic Acid Alleviated Alkaline Damage}

Our preliminary experiment showed that increasing the $\mathrm{Na}_{2} \mathrm{CO}_{3}$ concentration significantly increases MDA content and decreases chlorophyll content (Figure S1). The MDA content was the highest and the chlorophyll content was the lowest under $15 \mathrm{mM} \mathrm{Na}_{2} \mathrm{CO}_{3}$ treatment conditions. Therefore, the solution of $15 \mathrm{mM} \mathrm{Na}_{2} \mathrm{CO}_{3}$ was selected for the simulation of alkaline stress in this study.

Compared with the control treatment (non-ABA pretreatment), ABA pretreatment significantly reduced the rates of leaf wilting by $33.33 \%, 37.50 \%, 29.73 \%$, and $26.32 \%$ at $24 \mathrm{~h}$, $36 \mathrm{~h}, 48 \mathrm{~h}$, and $60 \mathrm{~h}$ after alkaline stress treatment, respectively (Figure 1C). Furthermore, ABA pretreatment also increased the survival rate of alfalfa seedlings by 1.88 -fold and 3.99 -fold at $48 \mathrm{~h}$ and $60 \mathrm{~h}$, respectively (Figure 1D), fresh weight by $21.11 \%$, and water content by $3.91 \%$ at $60 \mathrm{~h}$ after alkaline stress treatment (Figure 1E,F).

In addition, $\mathrm{ABA}$ pretreatment significantly decreased the $\mathrm{Na}^{+}$content (Figure S2A), but significantly increased the $\mathrm{K}^{+} / \mathrm{Na}^{+}$(Figure S2E), $\mathrm{Ca}^{2+} / \mathrm{Na}^{+}$(Figure S2F), and $\mathrm{Mg}^{2+} / \mathrm{Na}^{+}$ (Figure S2G) ratios and $\mathrm{Ca}^{2+}$ content (Figure S2C) in alfalfa leaves when $10 \mu \mathrm{M}$ and $20 \mu \mathrm{M}$ concentrations of ABA were applied under alkaline stress. The $\mathrm{Na}^{+}$content under alkaline stress showed no significant differences among the ABA concentrations of $10 \mu \mathrm{M}, 20 \mu \mathrm{M}$, and $30 \mu \mathrm{M}$ (Figure S2A). The contents of ions in the leaves of fluridone-treated seedlings were similar to those in the control treatment (Figure S2A-G).

3.2. Priming with Abscisic Acid Reduced Accumulation of Reactive Oxygen Species and Increased Activities of Antioxidant Enzymes

Alkaline stress induced high accumulation of MDA (Figure 2A), $\mathrm{H}_{2} \mathrm{O}_{2}$ (Figure 2B), and $\mathrm{O}_{2}{ }^{\bullet-}$ (Figure $2 \mathrm{C}$ ), which was reduced significantly by ABA pretreatment.

In addition, the activities of the antioxidant enzymes SOD (at $24 \mathrm{~h}, 36 \mathrm{~h}$, and $48 \mathrm{~h}$; Figure 3A) and POD (at $36 \mathrm{~h}$ and $48 \mathrm{~h}$; Figure 3B) were significantly increased by ABA pretreatment under alkaline stress. 

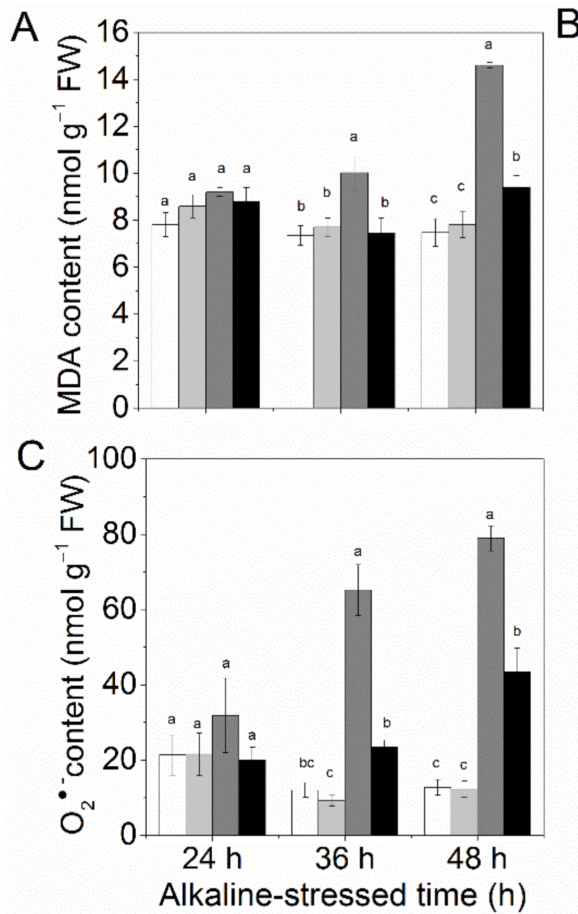

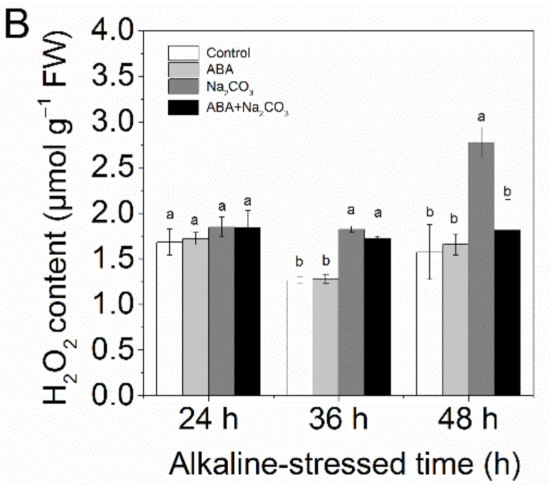

Alkaline-stressed time (h)

Figure 2. Abscisic acid (ABA) priming decreased MDA content and ROS accumulation in alfalfa (Medicago sativa L.) seedlings under alkaline stress. Eighteen-day-old alfalfa seedlings were rootdrenched with $10 \mu \mathrm{M}$ ABA or without ABA (Control) for $16 \mathrm{~h}$ and then exposed to unstressed (Control and $\mathrm{ABA})$ or alkaline-stressed $\left(\mathrm{Na}_{2} \mathrm{CO}_{3}\right.$ and $\left.\mathrm{ABA}+\mathrm{Na}_{2} \mathrm{CO}_{3}, 15 \mathrm{mM} \mathrm{Na} \mathrm{CO}_{3}\right)$ conditions. Accumulation of (A) malonaldehyde (MDA), (B) $\mathrm{H}_{2} \mathrm{O}_{2}$, and (C) $\mathrm{O}_{2}{ }^{\bullet-}$ in the leaves was determined after $24 \mathrm{~h}, 36 \mathrm{~h}$, and $48 \mathrm{~h}$ of alkaline treatment. Values are the mean \pm standard error, $\mathrm{n}=3$. Different letters above the columns indicate significant differences $(p<0.05)$ at each time point based on Duncan's test.
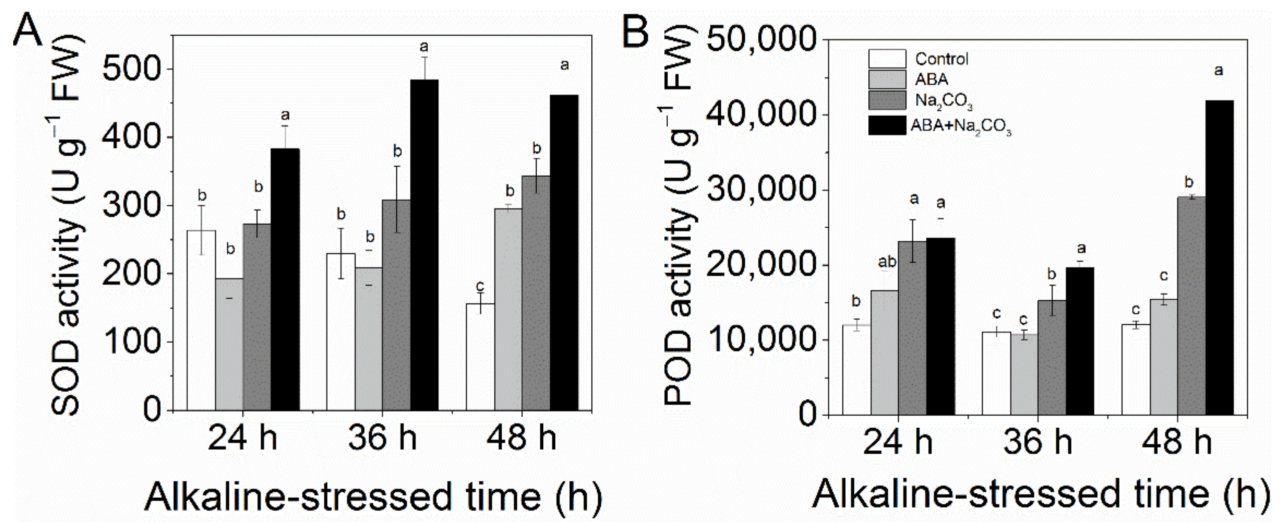

Figure 3. Abscisic acid (ABA) priming increased the activity of antioxidant enzymes and upregulated the expression of ROS-scavenging genes in alfalfa (Medicago sativa L.) seedlings under alkaline stress. Eighteen-day-old alfalfa seedlings were root-drenched with $10 \mu \mathrm{M}$ ABA or without ABA (Control) for $16 \mathrm{~h}$ and then exposed to unstressed (Control and $\mathrm{ABA}$ ) or alkaline-stressed $\left(\mathrm{Na}_{2} \mathrm{CO}_{3}\right.$ and $\mathrm{ABA}+\mathrm{Na}_{2} \mathrm{CO}_{3}, 15 \mathrm{mM} \mathrm{Na}_{2} \mathrm{CO}_{3}$ ) conditions. The activities of (A) superoxide dismutase (SOD) and (B) and peroxidase (POD) enzymes were measured at $24 \mathrm{~h}, 36 \mathrm{~h}$, and $48 \mathrm{~h}$ of alkaline treatment. Values are the mean \pm standard error, $n=3$. Different letters on the columns indicate significant differences $(p<0.05)$ at each time point based on Duncan's test. 


\subsection{Priming with Abscisic Acid Enhanced Ion Homeostasis and Proline Accumulation}

Alkaline stress increased the accumulation levels of $\mathrm{Na}^{+}$(Figure 4A) and $\mathrm{K}^{+}$(Figure 4B) in alfalfa leaves but decreased the contents $\mathrm{Ca}^{2+}$ (Figure 4C) and $\mathrm{Mg}^{2+}$ (Figure 4D). ABA pretreatment increased the ratios of $\mathrm{K}^{+} / \mathrm{Na}^{+}$(Figure $4 \mathrm{E}$ ), $\mathrm{Ca}^{2+} / \mathrm{Na}^{+}$(Figure $4 \mathrm{~F}$ ), and $\mathrm{Mg}^{2+} / \mathrm{Na}^{+}$ (Figure $4 \mathrm{G}$ ) compared with the control treatment.
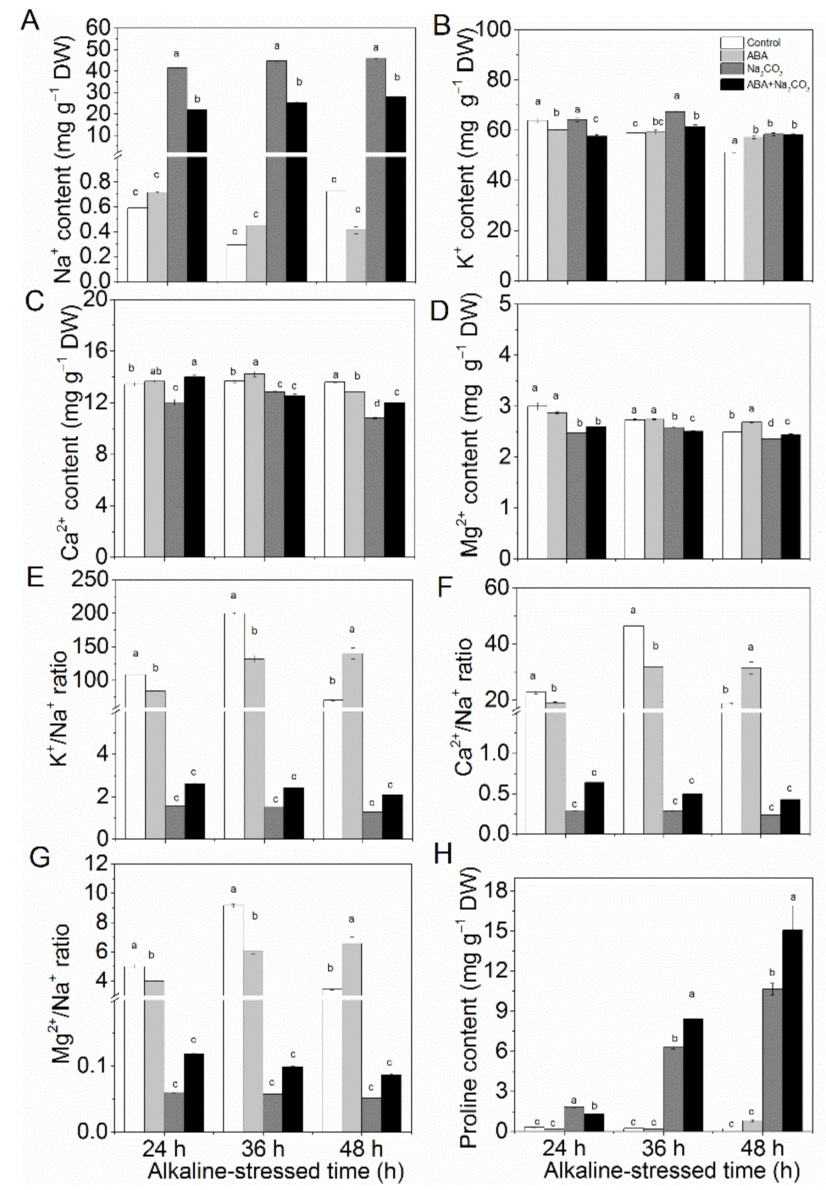

Figure 4. Abscisic acid (ABA) priming regulated ion homeostasis in alfalfa (Medicago sativa L.) seedlings under alkaline stress. Eighteen-day-old alfalfa seedlings were root-drenched with $10 \mu \mathrm{M}$ ABA or without ABA (Control) for $16 \mathrm{~h}$ and then exposed to unstressed (Control and ABA) or alkaline-stressed $\left(\mathrm{Na}_{2} \mathrm{CO}_{3}\right.$ and $\left.\mathrm{ABA}+\mathrm{Na}_{2} \mathrm{CO}_{3}, 15 \mathrm{mM} \mathrm{Na}_{2} \mathrm{CO}_{3}\right)$ conditions. (A) $\mathrm{Na}^{+}$content, (B) $\mathrm{K}^{+}$ content, (C) $\mathrm{Ca}^{2+}$ content, (D) $\mathrm{Mg}^{2+}$ content, (E) $\mathrm{K}^{+} / \mathrm{Na}^{+}$ratio, (F) $\mathrm{Ca}^{2+} / \mathrm{Na}^{+}$ratio, $(\mathrm{G}) \mathrm{Mg}^{2+} / \mathrm{Na}^{+}$ ratio, and $(\mathbf{H})$ proline contents were determined after $24 \mathrm{~h}, 36 \mathrm{~h}$, and $48 \mathrm{~h}$ of alkaline treatment. Values are the mean \pm standard error, $\mathrm{n}=3$. Different letters above the columns indicate significant differences $(p<0.05)$ at each time point based on Duncan's test.

The contents of the osmoprotective compound proline increased significantly under alkaline stress (Figure $4 \mathrm{H}$ ), which was further increased by ABA pretreatment by $33.42 \%$ at $36 \mathrm{~h}$ and $41.45 \%$ at $48 \mathrm{~h}$ after alkaline treatment.

\subsection{Priming with Abscisic Acid Upregulated Stress Tolerance-Related Genes}

Quantitative real-time PCR (qRT-PCR) showed that ABA pretreatment significantly upregulated expression of the antioxidant enzyme genes $\mathrm{CuZnSOD}$ (Figure 5A) and $P O D$ (Figure 5B), the stress tolerance-related genes NHX1 (Figure 5C) and AVP (Figure 5D), and the proline synthesis gene P5CS (Figure 5E) under alkaline stress. In addition, the relative expression of NHX1 in the ABA pretreatment reached to the highest value at $36 \mathrm{~h}$ and then decreased at $48 \mathrm{~h}$ (Figure 5C), whereas the expression of $A V P$ peaked at $24 \mathrm{~h}$ and then gradually decreased at 36 and $48 \mathrm{~h}$ under alkaline stress (Figure 5D). Moreover, ABA 
pretreatment induced the highest expression of P5CS at $24 \mathrm{~h}$, and then gradually decreased at 36 and $48 \mathrm{~h}$ under alkaline stress (Figure 5E).
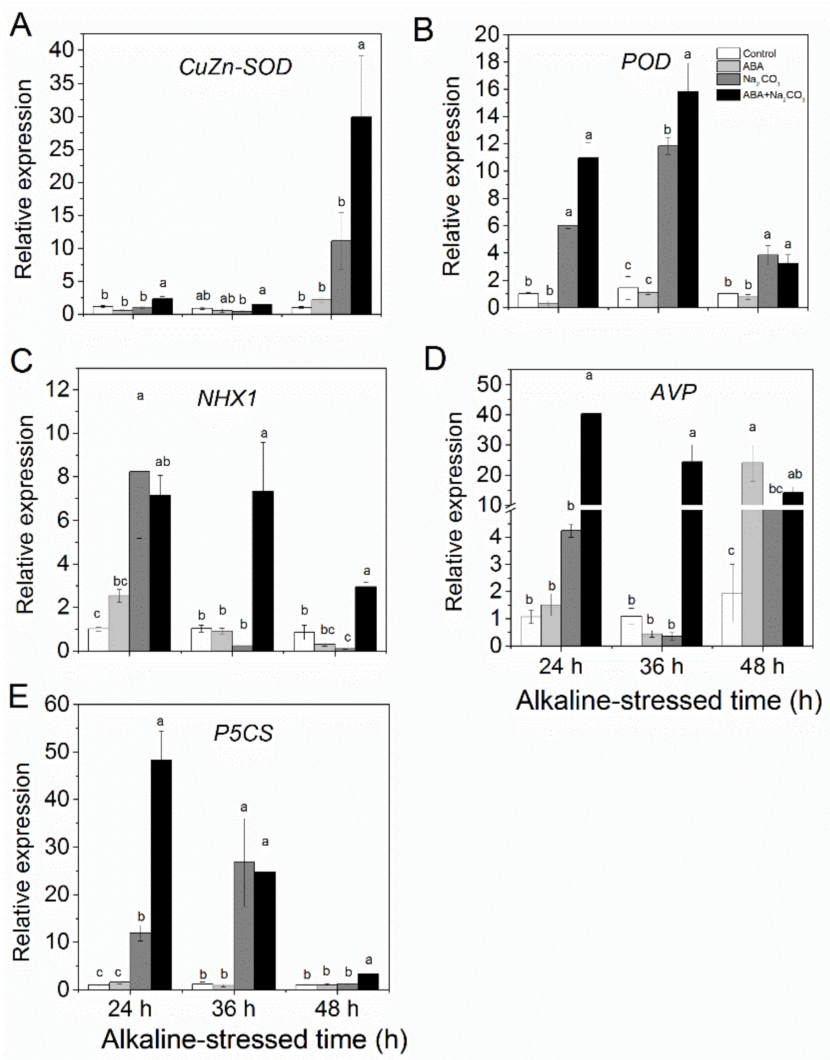

Alkaline-stressed time $(\mathrm{h})$

Figure 5. Abscisic acid (ABA) priming upregulated the relative expression of the ion transport genes (A) CuZnSOD, (B) POD, (C) NHX1, (D) AVP, and (E) P5CS in alfalfa (Medicago sativa L.) leaves under alkaline stress. Eighteen-day-old alfalfa seedlings were root-drenched with $10 \mu \mathrm{M}$ ABA or without ABA (Control) for $16 \mathrm{~h}$ and then exposed to unstressed (Control and ABA) or alkaline-stressed $\left(\mathrm{Na}_{2} \mathrm{CO}_{3}\right.$ and $\left.\mathrm{ABA}+\mathrm{Na}_{2} \mathrm{CO}_{3}, 15 \mathrm{mM} \mathrm{Na}_{2} \mathrm{CO}_{3}\right)$ conditions. Values are the mean \pm standard error, $\mathrm{n}=3$. Different letters above the columns indicate significant differences $(0.05)$ at each time point based on Duncan's test. The relative expression levels were analyzed by qRT-PCR and normalized against the internal reference gene Actin 2, which was stably expressed. The expression levels of unpretreated control (Control) at the indicated times were set as the unit to calculate the expression levels, shown as fold changes relative to the control at the indicated times.

\section{Discussion}

The high salinity and alkalinity of saline-alkaline (SA) stress seriously inhibit plant growth by causing osmotic shock and ion toxicity $[1,2,6,7]$. Of the two SA stress factors, high alkalinity is the primary factor limiting plant growth [40]. In alfalfa, alkaline stress causes severe wilting of seedlings and oxidative damage $[1,6]$ and disrupts the ion balance $[2,7,12]$ and osmotic homeostasis [2,7]. Therefore, the method to improve the productivity of alfalfa is to improve the tolerance to SA stress. In the present study, we showed that ABA pretreatment significantly alleviated leaf damage and increased the fresh weight, water content, and survival rate of alfalfa seedlings under alkaline stress (Figure 1). Our study revealed that these effects of $\mathrm{ABA}$ priming on alfalfa might be associated with decreased ROS accumulation (Figure 2), thus increasing the antioxidant enzyme activities (Figure 3), changing ion and osmotic homeostasis (Figure 4), and upregulating the expression of stress tolerance-related genes (Figure 5). These data indicated a molecular basis of the ABA-primed alkaline tolerance in alfalfa seedlings.

Priming is a cost-effective and environmentally friendly agrobiological technique, which improves plant growth by increasing resistance to diverse biotic and abiotic stresses [28,41,42]. 
$\mathrm{ABA}$ is a potent priming phytohormone that increases the tolerance to various stresses in diverse plant species $[31,43,44]$. In alfalfa, ABA treatment has been shown to improve stress tolerance to salt [33] and cold [34]. However, few studies have reported on the effect of ABA priming against alkaline stress $[9,11,32]$. In the present study, ABA application significantly mitigated leaf withering and increased seedling survival rates (Figure 1), suggesting that ABA priming can be a new practical approach to improve alfalfa adaptive planting in soil with high alkalinity. Despite the promise of ABA priming for stress tolerance, the obstacles to the use of ABA as a priming agent include the prohibitively high cost-still several hundred US dollars per gram, and unstable characteristics in the field, both metabolically and related to light-sensitivity $[45,46]$. However, some representative ABA agonists have been discovered, such as pyrabactin [47,48], ABA mimic-1 (AM1)/quinabactin [45,49], and S7 [50]. These compounds induce stress responses in plants similar to that of ABA and increase plant tolerance to diverse abiotic stresses, including drought [45,49] and cold [46]. Although their effects on plant responses to SA stress are unclear, they may have great potential uses as agrochemicals in the future [50].

ROS accumulation is associated with most abiotic and biotic stresses and causes oxidative damage to plants [51]. Although small amounts of ROS are used as signal molecules, when the ROS homeostasis is disturbed, excessive accumulation of ROS leads to damage to plant cells, eventually resulting in cell death $[19,20,52]$. An et al. [1] found that antioxidation and detoxification in alfalfa have important roles in response to SA stress. In this study, ABA pretreatment significantly reduced the accumulation of ROS (Figure 2), increased the antioxidant enzyme activities of SOD and POD (Figure 3A,B), and enhanced the expression levels of ROS-scavenging genes under alkaline conditions (Figure 5A,B). These data suggest that ABA pretreatment increased tolerance to the alkaline conditions at least partly by activating the antioxidant defense system in alfalfa seedlings.

Plants exposed to saline stress usually accumulate extra sodium, thus resulting in imbalances among available nutrient elements and competitive absorption, translocation, or distribution, ultimately affecting normal plant metabolism $[53,54]$. Notably, compared with the control, the $\mathrm{K}^{+}$content in alfalfa leaves increased after prolonged exposure to alkaline stress (Figure 4B), indicating that the maintenance of adequate $\mathrm{K}^{+}$in plant tissues under salt stress depends on the selective uptake of $\mathrm{K}^{+}$and the selective cellular compartmentalization and distribution of $\mathrm{K}^{+}$and $\mathrm{Na}^{+}$in the shoots [55]. Moreover, increasing evidence suggests that maintaining adequate $\mathrm{Ca}^{2+}$ and $\mathrm{Mg}^{2+}$ concentrations contributes to signaling and homeostasis of ions and enzyme activity under alkaline conditions [10]. A widely used critical marker of saline or SA tolerance is the ratio of $\mathrm{K}^{+} / \mathrm{Na}^{+}$[56-59]. Additional important markers reflecting saline or SA tolerance are the ratios of $\mathrm{Ca}^{2+} / \mathrm{Na}^{+}[2,18]$ and $\mathrm{Mg}^{2+} / \mathrm{Na}^{+}[2,60]$. In this study, ABA pretreatment resulted in a significant increase in the $\mathrm{Ca}^{2+}$ content at $24 \mathrm{~h}$ and $48 \mathrm{~h}$, and the $\mathrm{Mg}^{2+}$ content at $48 \mathrm{~h}$ (Figure $4 \mathrm{C}, \mathrm{D}$ ). In addition, the $\mathrm{K}^{+} / \mathrm{Na}^{+}, \mathrm{Ca}^{2+} / \mathrm{Na}^{+}$, and $\mathrm{Mg}^{2+} / \mathrm{Na}^{+}$ratios in the ABA pretreatment were higher than those in the pretreatment without ABA under alkaline conditions (Figure 4E-G). Furthermore, some important proteins involved in the sequestration of $\mathrm{Na}^{+}$in vacuoles, such as vacuolar $\mathrm{Na}^{+} / \mathrm{H}^{+}$exchanger $(\mathrm{NHX})$ and vacuolar $\mathrm{H}^{+}$-PPase $(A V P)$, play pivotal roles in the leaves of plants against salinity [15]. In this study, ABA priming significantly decreased the $\mathrm{Na}^{+}$content under alkaline conditions (Figure $4 \mathrm{~A}$ ) and increased the expression levels of the stress tolerance-related genes $N H X 1$ and $A V P$ (Figure 5C,D), indicating that ABA pretreatment could alleviate the toxicity of $\mathrm{Na}^{+}$by preventing excessive cytosolic $\mathrm{Na}^{+}$accumulation with the compartmentalization of $\mathrm{Na}+$ into vacuoles via upregulating the corresponding vacuolar genes $N H X$ and $A V P$ [13,54,61,62]. Collectively, the results revealed that the maintenance of ion homeostasis is another molecular mechanism that can explain the ABA priming effect.

Proline is an osmotic substance participating in the physiological response that protects plants through osmotic regulation $[63,64]$ and is also a nontoxic source of carbon, nitrogen, and energy reserves [65]. In addition, proline is an ROS scavenger that helps to protect cells from damage caused by stress [66]. In this study, the accumulation levels 
of proline were increased by $\mathrm{ABA}$ pretreatment in alfalfa leaves under alkaline stress (Figure $4 \mathrm{H}$ ). Consistently, the expression level of P5CS was increased by the ABA pretreatment (Figure 5E). These findings are consistent with previous studies in which primed plants increase the proline content in response to salt stress $[31,67]$. Thus, ABA pretreatment may also increase alkaline tolerance by increasing osmoprotection in alfalfa leaves.

In our study, although ABA priming created alkaline tolerance in alfalfa seedlings by the root-drenching with $\mathrm{ABA}$, there is still a limitation to practical application in SA fields for alfalfa planting. Therefore, we may need to determine the effect of ABA agonists and develop more effective treatment methods in the future studies, such as spraying onto the leaves, which should provide new approaches to enhance alkaline tolerance and improve alfalfa production.

\section{Conclusions}

In summary, ABA priming increases the tolerance to alkaline stress in alfalfa seedlings by maintaining homeostasis of ROS and metal ions and by upregulating osmoprotection and genes related to stress tolerance. The study provides new insight into the ABA priming mechanisms responsible for increasing alkaline stress tolerance in alfalfa and may provide a reference when applying signal molecules for increasing the alkaline tolerance of other plants in future studies.

Supplementary Materials: The following are available online at https:/ /www.mdpi.com/article/10 .3390/agriculture11070608/s1, Table S1: Primer pairs for stress-responsive genes used in reverse transcription qPCR; Figure S1: Effects of different concentrations of $\mathrm{Na}_{2} \mathrm{CO}_{3}$ on the (A) malondialdehyde (MDA) and (B) chlorophyll contents in the leaves of alfalfa (Medicago sativa L.) seedlings. Different letters above the columns indicate significant differences $(p<0.05)$ among concentrations based on Duncan's test. Figure S2: Abscisic acid (ABA) priming alleviated damage to alfalfa (Medicago sativa L.) seedlings under alkaline conditions. Eighteen-day-old alfalfa seedlings were also root-drenched with an ABA concentration of $0,10,20$, or $30 \mu \mathrm{M}$ or with fluridone (an ABA biosynthesis inhibitor, $10 \mu \mathrm{M})$ for $16 \mathrm{~h}$ and then exposed to alkaline stress $\left(15 \mathrm{mM} \mathrm{Na}_{2} \mathrm{CO}_{3}\right.$ ). (A) $\mathrm{Na}^{+}$content; (B) $\mathrm{K}^{+}$ content; (C) $\mathrm{Ca}^{2+}$ content; (D) $\mathrm{Mg}^{2+}$ content; (E) $\mathrm{K}^{+} / \mathrm{Na}^{+}$ratio; (F) $\mathrm{Ca}^{2+} / \mathrm{Na}_{+}$ratio; (G) $\mathrm{Mg}^{2+} / \mathrm{Na}^{+}$ ratio. Values are the mean \pm standard error, $\mathrm{n}=3$. Different letters on the columns indicate significant differences $(p<0.05)$ ( $\mathrm{a}$ to g) between ABA treatments and fluridone treatment based on Duncan's test.

Author Contributions: Conceptualization, C.-J.J. and Z.-W.L.; validation, C.-J.J. and Z.-W.L.; investigation, T.-J.W., M.-M.W., Y.-Y.J., G.-H.Z., M.L., and H.-Y.Y.; writing-original draft, T.-J.W.; writing - review and editing, C.-J.J. All authors have read and agreed to the published version of the manuscript.

Funding: This research was supported by the National Natural Science Foundation of China (41271522); the National Basic Research Program (973 Program) of China (2015CB150800); the Program of Science and Technology development of Jilin province (20200201018JC); Major Science and Technology Innovation Project of Shandong Province (2019JZZY010726); special fund project for science and technology cooperation high-tech industrialization of Jilin Province and Chinese Academy of Sciences (20190725009).

Institutional Review Board Statement: Not applicable.

Informed Consent Statement: Not applicable.

Conflicts of Interest: The authors declare no conflict of interest.

\section{References}

1. An, Y.M.; Song, L.L.; Liu, Y.R.; Shu, Y.J.; Guo, C.H. Denovo transcriptional analysis of alfalfa in response to saline-alkaline stress. Front. Plant Sci. 2016, 7, 931. [CrossRef]

2. Wei, T.J.; Jiang, C.J.; Jin, Y.Y.; Zhang, G.H.; Wang, M.M.; Liang, Z.W. $\mathrm{Ca}^{2+} / \mathrm{Na}^{+}$ratio as a critical marker for field evaluation of saline-alkaline tolerance in alfalfa (Medicago sativa L.). Agronomy 2020, 10, 191. [CrossRef]

3. Wong, V.; Greene, R.; Dalal, R.; Murphy, B.W. Soil carbon dynamics in saline and sodic soils: A review. Soil Use Manag. 2009, 26, 2-11. [CrossRef] 
4. $\quad$ Pandey, V.C.; Singh, K.; Singh, B.; Singh, R.P. New Approaches to Enhance Eco-Restoration Efficiency of Degraded Sodic Lands: Critical Research Needs and Future Prospects. Ecol. Restor. 2011, 29, 322-325. [CrossRef]

5. Guo, R.; Shi, L.X.; Yan, C.R.; Zhong, X.L.; Gu, F.X.; Liu, Q.; Xia, X.; Li, H.R. Ionomic and metabolic responses to neutral salt or alkaline salt stresses in maize (Zea mays L.) seedlings. BMC Plant Biol. 2017, 17, 41. [CrossRef] [PubMed]

6. $\quad$ Long, R.C.; Sun, H.; Cao, C.Y.; Zhang, T.J.; Kang, J.M.; Wang, Z.; Li, M.N.; Gao, Y.L.; Li, X.; Yang, Q.C. Identification of alkaliresponsive proteins from early seedling stage of two contrasting Medicago species by iTRAQ-based quantitative proteomic analysis. Environ. Exp. Bot. 2019, 157, 26-34. [CrossRef]

7. Peng, Y.L.; Gao, Z.W.; Gao, Y.; Liu, G.F.; Sheng, L.X.; Wang, D.L. Eco-physiological characteristics of alfalfa seedlings in response to various mixed salt-alkaline stresses. J. Integr. Plant Biol. 2008, 50, 29-39. [CrossRef]

8. Zhang, H.; Liu, X.-L.; Zhang, R.-X.; Yuan, H.-Y.; Wang, M.-M.; Yang, H.-Y.; Ma, H.-Y.; Liu, D.; Jiang, C.-J.; Liang, Z.-W. Root Damage under Alkaline Stress Is Associated with Reactive Oxygen Species Accumulation in Rice (Oryza sativa L.). Front. Plant Sci. 2017, 8, 1580. [CrossRef] [PubMed]

9. Liu, X.-L.; Zhang, H.; Jin, Y.-Y.; Wang, M.-M.; Yang, H.-Y.; Ma, H.-Y.; Jiang, C.-J.; Liang, Z.-W. Abscisic acid primes rice seedlings for enhanced tolerance to alkaline stress by upregulating antioxidant defense and stress tolerance-related genes. Plant Soil 2019, 438, 39-55. [CrossRef]

10. Yin, Z.P.; Zhang, H.; Zhao, Q.; Yoo, M.J.; Zhu, N.; Yu, J.L.; Guo, S.Y.; Miao, Y.C.; Chen, S.X.; Qi, Z.; et al. Physiological and comparative proteomic analyses of saline-alkali $\mathrm{NaHCO}_{3}$-responses in leaves of halophyte Puccinellia tenuiflora. Plant Soil 2019, 437, 137-158. [CrossRef]

11. Wei, L.X.; Lv, B.S.; Wang, M.M.; Ma, H.Y.; Yang, H.Y.; Liu, X.L.; Jiang, C.J.; Liang, Z.W. Priming effect of abscisic acid on alkaline stress tolerance in rice (Oryza sativa L.) seedlings. Plant Physiol. Biochem. 2015, 90, 50-57. [CrossRef] [PubMed]

12. Wang, X.S.; Ren, H.L.; Wei, Z.W.; Wang, Y.W.; Ren, W.B. Effects of neutral salt and alkali on ion distributions in the roots, shoots, and leaves of two alfalfa cultivars with differing degrees of salt tolerance. J. Integr. Agric. 2017, 16, 1800-1807. [CrossRef]

13. Munns, R.; Tester, M. Mechanisms of salinity tolerance. Annu. Rev. Plant Biol. 2008, 59, 651-681. [CrossRef]

14. Isah, T. Stress and defense responses in plant secondary metabolites production. Biol. Res. 2019, 52, 39. [CrossRef]

15. Sandhu, D.; Cornacchione, M.V.; Ferreira, J.F.S.; Suarez, D.L. Variable salinity responses of 12 alfalfa genotypes and comparative expression analyses of salt-response genes. Sci. Rep. 2017, 7, 42958. [CrossRef]

16. Ashrafi, E.; Razmjoo, J.; Zahedi, M.; Pessarakli, M. Selecting alfalfa cultivars for salt tolerance based on some physiochemical traits. Agron. J. 2014, 106, 1758-1764. [CrossRef]

17. Adem, G.D.; Roy, S.J.; Zhou, M.X.; Bowman, J.P.; Shabala, S. Evaluating contribution of ionic, osmotic and oxidative stress components towards salinity tolerance in barley. BMC Plant Biol. 2014, 14, 113. [CrossRef] [PubMed]

18. Anower, M.R.; Mott, I.W.; Peel, M.D.; Wu, Y.J. Characterization of physiological responses of two alfalfa half-sib families with improved salt tolerance. Plant Physiol. Biochem. 2013, 71, 103-111. [CrossRef]

19. Sewelam, N.; Kazan, K.; Schenk, P.M. Global plant stress signaling: Reactive oxygen species at the cross-road. Front. Plant Sci. 2016, 7, 187. [CrossRef]

20. Choudhury, F.K.; Rivero, R.M.; Blumwald, E.; Mittler, R. Reactive oxygen species, abiotic stress and stress combination. Plant J. 2017, 90, 856-867. [CrossRef]

21. Liu, D.; Liu, M.; Liu, X.L.; Cheng, X.G.; Liang, Z.W. Silicon priming created an enhanced tolerance in alfalfa (Medicago sativa L.) seedlings in response to high alkaline stress. Front. Plant Sci. 2018, 9, 716. [CrossRef] [PubMed]

22. Li, W.F.; Wang, D.L.; Jin, T.C.; Chang, Q.; Yin, D.X.; Xu, S.M.; Liu, B.; Liu, L.X. The Vacuolar $\mathrm{Na}^{+} / \mathrm{H}^{+}$antiporter gene SsNHX1 from the Halophyte Salsola soda confers salt tolerance in transgenic alfalfa (Medicago sativa L.). Plant Mol. Biol. Rep. 2011, 29, 278-290. [CrossRef]

23. Quan, W.L.; Liu, X.; Wang, H.Q.; Chan, Z.L. Physiological and transcriptional responses of contrasting alfalfa (Medicago sativa L.) varieties to salt stress. Plant Cell Tiss. Org. 2016, 126, 105-115. [CrossRef]

24. Ehsanpour, A.A.; Fatahian, N. Effects of salt and proline on Medicago sativa callus. Plant Cell Tissue Organ Cult. 2003, 73, 53-56. [CrossRef]

25. Amjad, M.; Akhtar, J.; Anwar-ul-Haq, M.; Yang, A.Z.; Akhtar, S.S.; Jacobsen, S.-E. Integrating role of ethylene and ABA in tomato plants adaptation to salt stress. Sci. Hortic. Amst. 2014, 172, 109-116. [CrossRef]

26. Yin, C.Y.; Duan, B.L.; Wang, X.; Li, C.Y. Morphological and physiological responses of two contrasting Poplar species to drought stress and exogenous abscisic acid application. Plant Sci. 2004, 167, 1091-1097. [CrossRef]

27. Chen, H.H.; Li, P.H.; Brenner, M.L. Involvement of abscisic Acid in potato cold acclimation. Plant Physiol. 1983, 71, 362-365. [CrossRef]

28. Conrath, U. Priming of Induced Plant Defense Responses. Adv. Bot. Res. 2009, 51, 361-395.

29. Pastor, V.; Luna, E.; Mauch-Mani, B.; Ton, J.; Flors, V. Primed plants do not forget. Environ Exp. Bot. 2013, 94, 46-56. [CrossRef]

30. Gao, Y.P.; Bonham-Smith, P.C.; Gusta, L.V. The role of peroxiredoxin antioxidant and calmodulin in ABA-primed seeds of Brassica napusexposed to abiotic stresses during germination. J. Plant Physiol. 2002, 159, 951-958. [CrossRef]

31. Gurmani, A.R.; Bano, A.; Khan, S.U.; Din, J.; Zhang, J.L. Alleviation of salt stress by seed treatment with abscisic acid (ABA), 6-benzylaminopurine (BA) and chlormequat chloride (CCC) optimizes ion and organic matter accumulation and increases yield of rice (Oryza sativa L.). Aust. J. Crop. Sci. 2011, 5, 1278-1285. 
32. Wei, L.-X.; Lv, B.-S.; Li, X.-W.; Wang, M.-M.; Ma, H.-Y.; Yang, H.-Y.; Yang, R.-F.; Piao, Z.-Z.; Wang, Z.-H.; Lou, J.-H.; et al. Priming of rice (Oryza sativa L.) seedlings with abscisic acid enhances seedling survival, plant growth, and grain yield in saline-alkaline paddy fields. Field Crop Res. 2017, 203, 86-93. [CrossRef]

33. Yang, Y.X.; Liu, D.L.; Han, J.G.; Zhao, G.Q.; Han, J.; Wang, X.S. Effects of ABA on the content of mineral element and proline of two alfalfa varieties under $\mathrm{NaCl}$ stress condition. Pratacultural Sci. 2010, 27, 57-61. (In Chinese)

34. Wang, Y.Z.; Ren, W.; Xu, A.K.; Wang, Z.F.; Deng, B. Physiological responses to exogenous SA and ABA in alfalfa varieties under chilling stress. Acta Agric. Boreali-Sin. 2012, 27, 144-149. (In Chinese)

35. Bates, L.S.; Waldren, R.P.; Teare, I.D. Rapid determination of free proline for water-stress studies. Plant Soil 1973, 39, $205-207$. [CrossRef]

36. Felix, K.; Su, J.C.; Lu, R.F.; Zhao, G.; Cui, W.T.; Wang, R.; Mu, H.L.; Cui, J.; Shen, W.B. Hydrogen-induced tolerance against osmotic stress in alfalfa seedlings involves ABA signaling. Plant Soil 2019, 445, 409-423. [CrossRef]

37. Zhang, C.M.; Shi, S.L.; Liu, Z.; Yang, F.; Yin, G.L. Drought tolerance in alfalfa (Medicago sativa L.) varieties is associated with enhanced antioxidative protection and declined lipid peroxidation. J. Plant. Physiol. 2019, 232, 226-240. [CrossRef] [PubMed]

38. Wang, X.M.; Fu, Y.Y.; Ban, L.P.; Wang, Z.; Feng, G.Y.; Li, J.; Gao, H.W. Selection of reliable reference genes for quantitative real-time RT-PCR in alfalfa. Genes Genet. Syst. 2015, 90, 175-180. [CrossRef]

39. Livak, K.J.; Schmittgen, T.D. Analysis of relative gene expression data using real-time quantitative PCR and the $2^{-\Delta \Delta C T}$ method. Methods 2001, 25, 402-408. [CrossRef]

40. Lv, B.S.; Li, X.W.; Ma, H.Y.; Sun, Y.; Wei, L.X.; Jiang, C.J.; Liang, Z.W. Differences in growth and physiology of rice in response to different saline-alkaline stress factors. Agron. J. 2013, 105, 1889. [CrossRef]

41. Beckers, G.J.M.; Conrath, U. Priming for stress resistance: From the lab to the field. Curr. Opin. Plant Biol. 2007, 10, 425-431. [CrossRef]

42. Savvides, A.; Ali, S.; Tester, M.; Fotopoulos, V. Chemical priming of plants against multiple abiotic stresses: Mission possible? Trends Plant Sci. 2016, 21, 329-340. [CrossRef]

43. Sripinyowanich, S.; Klomsakul, P.; Boonburapong, B.; Bangyeekhun, T.; Asami, T.; Gu, H.Y.; Buaboocha, T.; Chadchawan, S. Exogenous ABA induces salt tolerance in indica rice (Oryza sativa L.): The role of OsP5CS1 and OsP5CR gene expression during salt stress. Environ. Exp. Bot. 2013, 86, 94-105. [CrossRef]

44. Wang, G.J.; Miao, W.; Wang, J.Y.; Ma, D.R.; Li, J.Q.; Chen, W.F. Effects of exogenous abscisic acid on antioxidant aystem in weedy and cultivated rice with different chilling sensitivity under chilling stress. J. Agron. Crop Sci. 2013, 199, 200-208. [CrossRef]

45. Cao, M.; Liu, X.; Zhang, Y.; Xue, X.; Zhou, X.E.; Melcher, K.; Gao, P.; Wang, F.; Zeng, L.; Zhao, Y.; et al. An ABA-mimicking ligand that reduces water loss and promotes drought resistance in plants. Cell Res. 2013, 23, 1043-1054. [CrossRef]

46. Cheng, Z.M.; Jin, R.; Cao, M.J.; Liu, X.D.; Chan, Z.L. Exogenous application of ABA mimic 1 (AM1) improves cold stress tolerance in bermudagrass (Cynodon dactylon). Plant Cell Tiss. Org. 2016, 125, 231-240. [CrossRef]

47. Zhao, Y.; Chow, T.F.; Puckrin, R.S.; Alfred, S.E.; Korir, A.K.; Larive, C.K. Chemical genetic interrogation of natural variation uncovers a molecule that is glycoactivated. Nat. Chem. Biol. 2007, 3, 716-721. [CrossRef] [PubMed]

48. Park, S.Y.; Fung, P.; Nishimura, N.; Jensen, D.R.; Fujii, H.; Zhao, Y.; Lumba, S.; Santiago, J.; Rodrigues, A.; Chow, T.-F.; et al. Abscisic Acid Inhibits Type 2C Protein Phosphatases via the PYR/PYL Family of START Proteins. Science 2009, 324, $1068-1071$. [CrossRef]

49. Okamoto, M.; Peterson, F.C.; Defries, A.; Park, S.Y.; Endo, A.; Nambara, E.; Volkman, B.F.; Cutler, S.R. Activation of dimeric ABA receptors elicits guard cell closure, ABA-regulated gene expression, and drought tolerance. Proc. Natl. Acad. Sci. USA 2013, 110, 12132-12137. [CrossRef] [PubMed]

50. Min, M.K.; Kim, R.; Moon, S.J.; Lee, Y.; Han, S.; Lee, S.; Kim, B.-G. Selection and functional identification of a synthetic partial ABA agonist, S7. Sci. Rep. 2020, 10, 4. [CrossRef]

51. Demidchik, V. Mechanisms of oxidative stress in plants: From classical chemistry to cell biology. Environ. Exp. Bot. 2015, 109, 212-228. [CrossRef]

52. Mittler, R.; Blumwald, E. The roles of ROS and ABA in systemic acquired acclimation. Plant Cell 2015, 27, 64-70. [CrossRef]

53. Ashrafi, E.; Razmjoo, J.; Zahedi, M. Effect of salt stress on growth and ion accumulation of alfalfa (Medicago sativa L.) cultivars. J. Plant Nutr. 2018, 41, 818-831. [CrossRef]

54. Lei, Y.T.; Xu, Y.X.; Hettenhausen, C.; Lu, C.K.; Shen, G.J.; Zhang, C.P.; Li, J.; Song, J.; Lin, H.H.; Wu, J.Q. Comparative analysis of alfalfa (Medicago sativa L.) leaf transcriptomes reveals genotype-specific salt tolerance mechanisms. BMC Plant Biol. 2018, 18, 35. [CrossRef]

55. Carden, D.E.; Walker, D.J.; Flowers, T.J.; Miller, A.J. Single-cell measurements of the contributions of cytosolic $\mathrm{Na}^{+}$and $\mathrm{K}^{+}$to salt tolerance. Plant Physiol. 2003, 131, 676. [CrossRef]

56. Chen, Z.H. Potassium and sodium relations in salinised barley tissues as a basis of differential salt tolerance. Funct. Plant Biol. 2007, 2, 150-162. [CrossRef] [PubMed]

57. Fakhrfeshani, M.; Shahriari-Ahmadi, F.; Niazi, A.; Moshtaghi, N.; Zare-Mehrjerdi, M. The effect of salinity stress on Na ${ }^{+}, \mathrm{K}^{+}$ concentration, $\mathrm{Na}^{+} / \mathrm{K}^{+}$ratio, electrolyte leakage and HKT expression profile in roots of Aeluropus littoralis. J. Plant Mol. Breed. 2015, 3, 1-10.

58. Shabala, S.; Pottosin, I. Regulation of potassium transport in plants under hostile conditions: Implications for abiotic and biotic stress tolerance. Physiol. Plant. 2014, 151, 257-279. [CrossRef] [PubMed] 
59. Hauser, F.; Horie, T. A conserved primary salt tolerance mechanism mediated by HKT transporters: A mechanism for sodium exclusion and maintenance of high $\mathrm{K}^{+} / \mathrm{Na}^{+}$ratio in leaves during salinity stress. Plant Cell Environ. 2010, 33, 552-565. [CrossRef] [PubMed]

60. Bernstein, N.; Silk, W.K.; Läuchli, A. Growth and development of sorghum leaves under conditions of NaCl stress: Possible role of some mineral elements in growth inhibition. Planta 1995, 196, 699-705. [CrossRef]

61. Apse, M.P.; Aharon, G.S.; Snedden, W.A.; Blumwald, E. Salt tolerance conferred by overexpression of a vacuolar $\mathrm{Na}^{+} / \mathrm{H}^{+} \mathrm{Antiport}$ in Arabidopsis. Science 1999, 285, 1256-1258. [CrossRef]

62. Ding, M.Q.; Hou, P.C.; Shen, X.; Wang, M.J.; Deng, S.R.; Sun, J.; Xiao, F.; Wang, X.Y.; Zhou, X.Y.; Lu, C.F.; et al. Salt-induced expression of genes related to $\mathrm{Na}^{+} / \mathrm{K}^{+}$and ROS homeostasis in leaves of salt-resistant and salt-sensitive poplar species. Plant Mol. Biol. 2010, 73, 251-269. [CrossRef] [PubMed]

63. Majid, M.; Ali, A.; Essia, B. Effect of salinity on sodium and chloride uptake, proline and soluble carbohydrate contents in three alfalfa varieties. IOSR-JAVS 2012, 1, 1-6. [CrossRef]

64. Anower, M.R.; Peel, M.D.; Mott, I.W.; Wu, Y. Physiological processes associated with salinity tolerance in an alfalfa half-sib family. J. Agron. Crop Sci. 2017, 203, 506-518. [CrossRef]

65. Joyce, P.A.; Aspinall, D.; Paley, L.G. Photosynthesis and the accumulation of proline in response to water deficit. Funct. Plant Biol. 1992, 19, 249-261. [CrossRef]

66. Szabados, L.; Savouré, A. Proline: A multifunctional amino acid. Trends Plant Sci. 2010, 15, 89-97. [CrossRef] [PubMed]

67. Silva-Ortega, C.O.; Ochoa-Alfaro, A.E.; Reyes-Agüero, J.A.; Aguado-Santacruz, G.A.; Jiménez-Bremont, J.F. Salt stress increases the expression of P5CS gene and induces proline accumulation in cactus pear. Plant Physiol. Bioch. 2008, 46, 82-92. [CrossRef] 